Agr. Biol. Chem., 40 (11), 2209 2212, 1976

\title{
Inhibition of Tumor Growth In Vivo by Damavaricin C Derivatives
}

\author{
Kazukiyo OnODERA, Yoshitaka AOI and Kazuya SASAKI* \\ The Institute of Medical Science, The University of Tokyo, \\ Shiroganedai, Minato-ku, Tokyo 108 \\ * Research Laboratory, Kaken Chemical Co., Ltd., \\ Honkomagome, Bunkyo-ku, Tokyo 113, Japan
}

Recejved June 21, 1976

\begin{abstract}
We have previously reported the antitumor activity of some streptovaricin $\mathrm{C}$ derivatives selected for their ability to inhibit preferentially the growth of virus transformed cells and human derived cancer cells in vitro at relatively low concentrations. $n$-Butyl ether, 2-thenoylmethyl ether and the oxime of acetonyl ether derived from damavaricin $\mathrm{C}$ showed antitumor activity against ascites and solid Sarcoma 180 in vivo.
\end{abstract}

Streptovaricins were discovered by Siminoff et $a l .{ }^{1)}$ and have been studied for their potential antitubercular activity. Chemical studies of the streptovaricins have been made by Rinehart et al., ${ }^{2}$ ' who explored the correlation between chemical structure and biological activity. ${ }^{3)}$ During the course of the structural studies of streptovaricins, damavaricin C (DvC) was obtained by oxidative alkaline hydrolysis of streptovaricin $C^{4,51}$

DvC has a newly formed phenolic hydroxyl group at the $\mathrm{C}-19$ position of the naphthoquinone moiety of the molecule, thus enabling the preparation of a series of derivatives as shown in Fig. 1. A chemical study of these derivatives and the correlations between their structures and biological activities in terms of antimicrobial and antitumor activity in vitro have already been reported. ${ }^{4,6)}$

We wish to report here that some of the DvC derivatives have potential antitumor activity against Sarcoma 180 in vivo.

\section{MATERIALS AND METHODS}

Damavaricin $C$ and its derivatives. Crude streptovaricin was obtained from the Upjohn Co., Mich., U.S. A. Streptovaricin C was isolated from the streptovaricin complex in pure crystalline form as previously reported.4) Upon treatment with methanolic ammonia under oxidative conditions, streptovaricin $\mathrm{C}$ was converted into DvC (Fig. 1). The etherification of $\mathrm{DvC}$ at the $\mathrm{C}-19$ position and preparation of aldol compounds of this molecule have been reported in previous papers. ${ }^{4,8}$ ) The structures and codes of the derivatives used in this study are listed in Fig. 1.

Animals. Female ICR mice weighing $18 \sim 20 \mathrm{~g}$ were used. The effects on life prolongation and tumor growth using ascites and solid Sarcoma 180 were determined.

The assessment of antitumor activity. Tumor cells were suspended in sterile phosphate buffer saline and $5 \times 10^{8}$ cells of Sarcoma 180 were implanted either intraperitoneally or subcutaneously.

The derivatives were dissolved in $95 \%$ ethanol at the concentration of $10 \mathrm{mg} / \mathrm{ml}$, and this solution was diluted ten times with sterile saline before administration. The effect of the derivatives on survival time is shown in Table $I$ and Fig. 2, the inhibition of solid tumor growth being calculated from the average tumor weight respectively. The average tumor weight was measured on the 21 st day after implantation. Experimental details were shown in the legends.

\section{RESULTS}

Effect of the derivatives on ascites Sarcoma 180 in vivo.

Using 5 mice, the derivatives which are active against ascites Sarcoma 180 in vivo were selected from the following compounds: Streptovaricin A (1), B (2), C (3), D (4) and G (5), and 19-O-substituted DvC derivatives. such as ethyl ether (6), n-butyl ether (7), $n$ hexyl ether (8), 2-thenoylmethyl ether (9) acetonyl ether (10), aldol compound (11), acetonyl ether oxime (12), acetonyl ether O- 


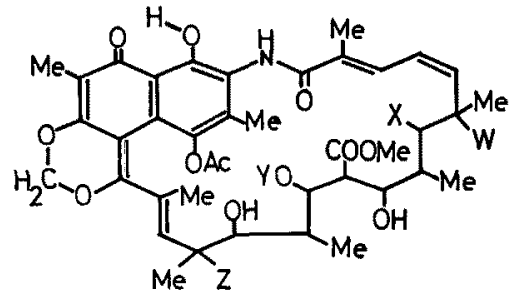

Streptovaricins

1 Streptovaricin A

2 Streptovaricin B

3 Streptovaricin C

4 Streptovaricin D

5 Streptovaricin G
Z

$\mathrm{OH}$

$\mathrm{OH}$

$\mathrm{OH}$

H

$\mathrm{OH}$

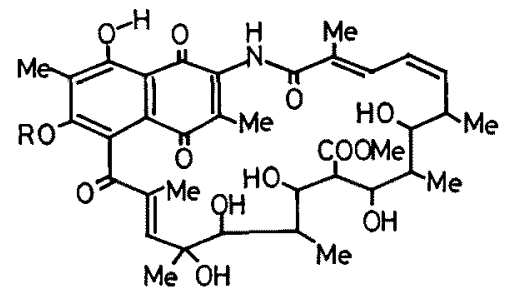

Damavaricin $\mathrm{C}(\mathrm{R}=\mathrm{H})$

Damavaricin $\mathrm{C}$ derivatives

(R)

6 ethyl

7 -butyl

$8 n$-hexyl

9 2-thenoylmethyl

10 acetonyl

11 hydroxyiminoacetonyl

12 methoxyiminoacetonyl

13 di- $n$-pentylhydrazonoacetonyl

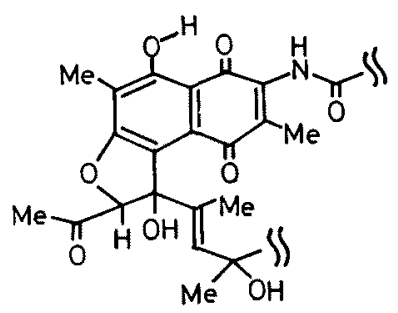

Aldol compound (11)

FIG. 1. Structures and Codes of Streptovaricins and Damavaricin C Derivatives.

methyloxime (13) and acetonyl ether di-npentylhydrazone (14).

The dose of each drug was $20 \mathrm{mg} / \mathrm{kg}$ every $24 \mathrm{hr}$ after the tumor implantation for 6 days. Antitumor activity was determined by comparing the mean of survival days (MSD)
Table I. EFfect of Streptovaricins and Damavaricin $C$ Derivatives on TUMOR Growth OF Mice BEARING Ascites Sarcoma 180 in vivo

\begin{tabular}{lccr}
\hline \multicolumn{1}{c}{ Compound } & $\begin{array}{c}\text { Dose } \\
(\mathrm{mg} / \mathrm{kg})^{a)}\end{array}$ & $\begin{array}{c}\left.\mathrm{MSD}^{b}\right) \\
(\text { days } \\
\text { S. D. })\end{array}$ & $\begin{array}{c}\text { ILS } \\
(\%)^{c}\end{array}$ \\
\hline $\begin{array}{l}\text { None (Untreated } \\
\text { mice) }\end{array}$ & - & $10.7 \pm 1.7$ & - \\
Streptovaricins: & & & \\
$\mathbf{1}$ & 20 & $10.8 \pm 1.8$ & 1 \\
$\mathbf{2}$ & 20 & $11.2 \pm 1.2$ & 5 \\
$\mathbf{3}$ & 20 & $12.3 \pm 1.6$ & 15 \\
$\mathbf{4}$ & 20 & $12.4 \pm 2.6$ & 16 \\
$\mathbf{5}$ & 20 & $12.4 \pm 2.6$ & 16
\end{tabular}

Damavaricin C derivatives:

$\begin{array}{rrrr}\mathbf{6} & 20 & 14.2 \pm 1.2 & 33 \\ \mathbf{7} & 20 & 12.8 \pm 1.8 & 20 \\ \mathbf{8} & 20 & 12.4 \pm 1.4 & 16 \\ \mathbf{9} & 20 & 12.8 \pm 2.2 & 20 \\ \mathbf{1 0} & 20 & 13.6 \pm 1.6 & 27 \\ \mathbf{1 1} & 20 & 14.2 \pm 1.2 & 33 \\ \mathbf{1 2} & 20 & 13.6 \pm 1.6 & 27 \\ \mathbf{1 3} & 20 & 11.6 \pm 2.6 & 8 \\ \mathbf{1 4} & 20 & 14.2 \pm 1.2 & 33\end{array}$

a) Administered intraperitoneally once daily for 6 consecutive days after the tumor implantation. ${ }^{5}$ MSD: mean of survival days. ${ }^{\circ}$ The percent increase of life span.

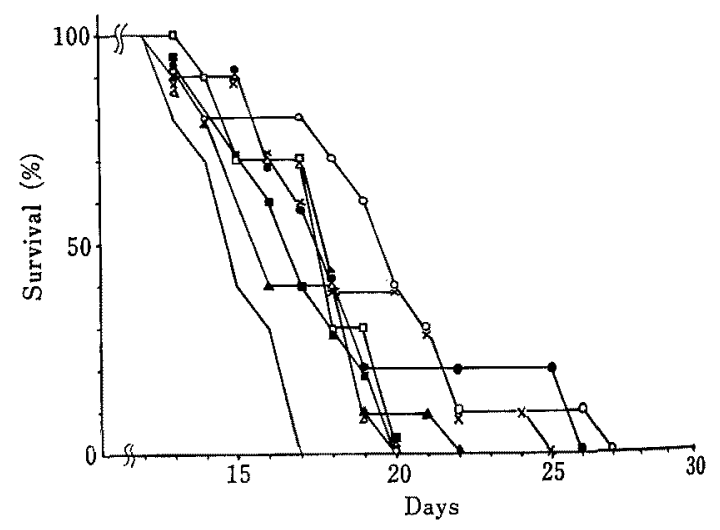

Fig. 2. Effect of Damavaricin C Derivatives on Ascites Sarcoma 180 Implanted in Mice.

- untreated control; $0-\bigcirc 9 ; \times-\times 12 ; \triangle-\triangle 6$;

$\bullet-7 ; \square-\square 10 ; \Delta-\wedge 11 ; \square-\square 12$.

with that of the control group. The percent increase of life span (\%ILS) was calculated from the mean of survival time. 
The results are shown in Table $\mathrm{I}$. DvC derivatives 6, 7, 9, 10, 11, 12 and 14 showed over $20 \%$ ILS at the first screening. These seven compounds were retested for their antitumor activity against ascites Sarcoma 180 using ten mice for each drug. The results are shown in Fig. 2. Derivatives 7 and 9 were most effective and $\mathbf{1 2}$ was effective to a lesser degree.

Effect of the derivatives on solid Sarcoma 180 in vivo.

Among the derivatives listed in Table I, 7, 9, 12 and 14 were tested for their antitumor activity against solid Sarcoma 180 in vivo. In

TABle II. In vivo EFFect of Damavaricin C Derivatives on Tumor Growth in Mice BeAring Solid SARCOMA 180

\begin{tabular}{rccc}
\hline Compound & $\begin{array}{c}\text { Dose } \\
(\mathrm{mg} / \mathrm{kg} / \\
\text { day })\end{array}$ & $\begin{array}{c}\text { Average } \\
\text { tumor } \\
\text { weight }(\mathrm{g})^{b)}\end{array}$ & $\begin{array}{c}\text { Inhibition } \\
\text { of tumor } \\
\text { growth } \\
(\%)\end{array}$ \\
\hline $\begin{array}{l}\text { None } \\
\text { (Untreated }\end{array}$ & & & \\
mice) & - & 1.81 & - \\
7 & 5 & 1.51 & 17.1 \\
$\mathbf{9}$ & 5 & 1.22 & 32.6 \\
$\mathbf{1 2}$ & 5 & 1.02 & 43.6 \\
$\mathbf{1 4}$ & 5 & 1.74 & 3.9 \\
\hline
\end{tabular}

a) Administered subcutaneously once daily for 20 consecutive days beginning $24 \mathrm{hr}$ after tumor implantation.

b) Average tumor weight as measured on 21 st day. the case of solid tumor, each drug was administered at a dose of $5 \mathrm{mg} / \mathrm{kg} /$ day. The tumor was excised on the 21 st day and the average tumor weight was measured. The results are shown in Table II. Acetonyl ether oxime (12) and 2-thenoylmethyl ether (9) showed $43.6 \%$ and $32.6 \%$ inhibition of tumor growth, respectively. $n$-Butyl ether (7) was less effective and acetonyl ether di- $n$-pentylhydrazone (14) was not effective. The photograph of the excised tumors grown in the presence of these compounds is shown in Fig. 3.

\section{DISCUSSION}

There are two reports suggesting that streptovaricins have potential antitumor activity: First, the growth of mammary tumor was significantly inhibited by the oral administration of streptovaricin complex ${ }^{8)}$ and secondly, it was reported that oral administration of this compound reduced splenomegaly induced in mice by Rauscher leukemia virus. ${ }^{91}$ These authors ascribed these observed effects to the inhibition of the reverse transcriptase of these RNA oncorna viruses by streptovaricins.

We, however, developed an in vitro screening procedures by which to select compounds with potential antitumor activity using the virus transformed cells and their normal counterparts. ${ }^{6}{ }^{6}$ The derivatives of $\mathrm{DvC}$ selected

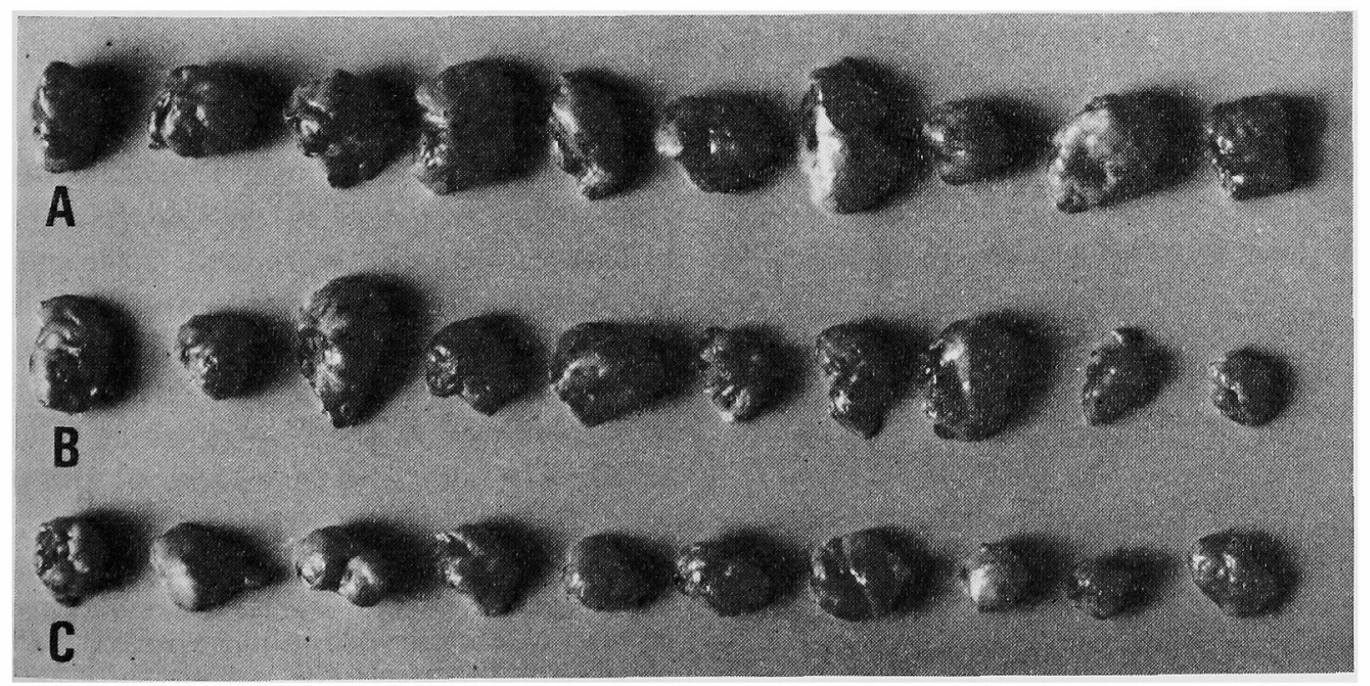

FIG. 3. A, without drug; B, 2-thenoylmethyl ether; C, oxime of acetonyl ether. 
according to this procedure showed cell growth inhibition. Therefore, it was expected that some of the derivatives had potential antitumor activity in vivo. We employed ascites and solid Sarcoma 180 as a model system.

A few compounds such as 7,9 and 12 showed antitumor activity against ascites and solid Sarcoma 180. Compound 14 was effective on the ascites Sarcoma 180 but not on solid Sarcoma 180.

It was reported from our laboratory that some derivatives of $\mathrm{DvC}$ were active against virus transformed cells of fibroblast cells while others were active against those of epithelial cells in vitro. ${ }^{6}$ Therefore, it is conceivable that some derivatives are active against one tumor type and the others against a different type in vivo. In this context it is interesting to note that acetonyl ether di-n-pentylhydrazone (14) was active against ascites Sarcoma 180 but not against solid Sarcoma 180 .

The dose used in this experiment was $20 \mathrm{mg} /$ $\mathrm{kg} /$ day for ascites tumor and $5 \mathrm{mg} / \mathrm{kg} /$ day for solid tumor. The dose was relatively low compared with other antitumor agents. DvC derivatives such as $n$-butyl ether (7), 2-thenoylmethyl ether (9) and acetonyl ether oxime (12) were not highly toxic to mice when administered subcutaneously or orally (unpublished observation). The dose response study of the derivatives is now in progress.

\section{REFERENCES}

1) P. Siminoff, R. M. Smith, W. T. Sokolski and G. M. Savage, Am. Rev. Tuberc. Pulm. Dis., 75, 576 (1957).

2) K. L. Rinehart, Jr., M. L. Maheshwari, K. Sasaki, R. J. Schacht, H. H. Mathur and F. J. Antosz, J. Am. Chem. Soc., 93, 6273 (1971).

3) K. L. Rinehart, Jr., F. J. Antosz, K. Sasaki, P. K. Martin, M. L. Maheshwari, F. Reusser, L. H. Li, D. Moran and P. F. Wilen, Biochem, 13, 861 (1974).

4) K. Sasaki, T. Naito, T. Satomi and K. Onodera, J. Antibiot., 29, 147 (1976),

5) K. L. Rinehart, Jr., F. J. Antosz, P. V. Deshmukh, K. Kakinuma, P. K. Martin, B. I. Milavetz, K. Sasaki and T. R. Witty, ibid., 29, 201 (1976).

6) K. Onodera, Y. Aoi and K. Sasaki, Agr. Biol. Chem., 40, 1381 (1976).

7) K. Sasaki, T. Naito, T. Satomi and Y. Momoki, J. Antibiot., 29, 199 (1976).

8) B. Kramarski and W. J. Manthey, Proc. Soc. Exp. Biol. Med., 145, 1434 (1974).

9) E. C. Borden, W. W. Brockman and W. A. Carter, Nature New Biol., 232, 214 (1971). 